\title{
Removal of Gasoline Vapors from Air Streams by Biofiltration
}

\author{
W. A. Apel \\ W. D. Kant \\ F. S. Colwell \\ B. Singleton \\ B. D. Lee \\ G. F. Andrews \\ A. M. Espinosa \\ E. G. Johnson
}

Published March 1993

\section{Idaho National Engineering Laboratory \\ EG\&G Idaho, Inc. Idaho Falls, Idaho 83415}




\section{Removal of Gasoline Vapors from Air Streams by Biofiltration}

EGG-WTD-10714

Prepared by

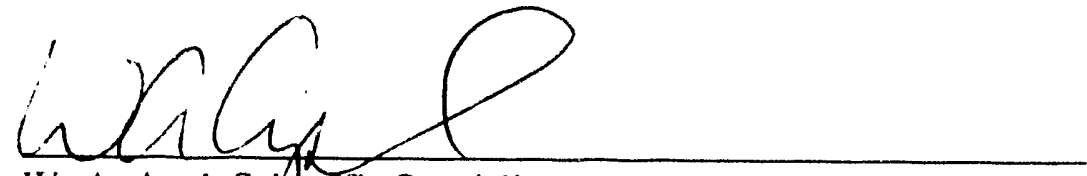

W. A. Apel, Scientific Specialist
Center for Biopyocessing and Environmental Assessment
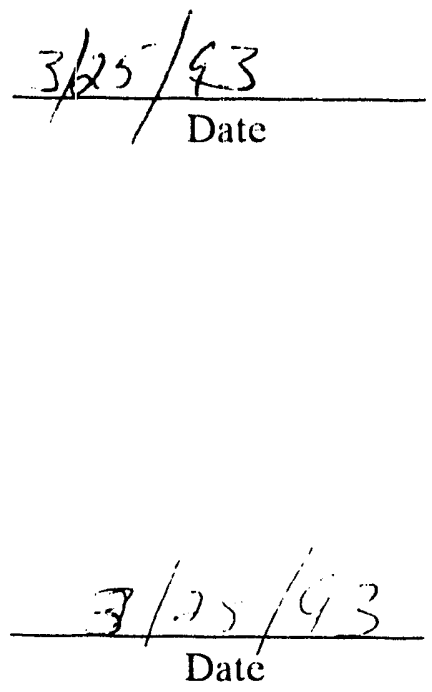

B. D. Lee, Scientist

Bioprocessing Engineering Unit

Approved by

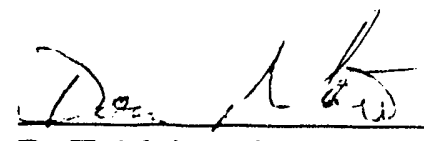

D. T. Maiers, S\&E Project Manager

Research and Development Unit

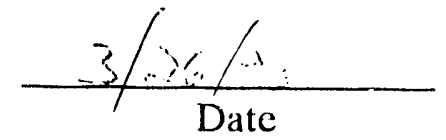




\begin{abstract}
Research was performed to develop a biofilter for the biodegradation of gasoline vapors. The overall goal of this effort was to provide information necessary for the design, construction, and operation of a commercial gasoline vapor biofilter. Experimental results indicated that relatively high amounts of gasoline vapor adsorption occur during initial exposure of the biofilter bed medium to gasoline vapors. Biological removal occurs over a 22 to $40^{\circ} \mathrm{C}$ temperature range with removal being completely inhibited at $54^{\circ} \mathrm{C}$. The addition of fertilizer to the relatively fresh bed medium used did not increase the rates of gasoline removal in short term experiments. Microbiological analyses indicated that high levels of gasoline degrading microbes are naturally present in the bed medium and that additional inoculation with hydrocarbon degrading cultures does not appreciably increase gasoline removal rates. At lower gasoline concentrations, the vapor removal rates were considerably lower than those at higher gasoline concentrations. This implies that system designs facilitating gasoline transport to the micro-organisms could substantially increase gasoline removal rates at lower gasoline vapor concentrations. Test results from a field scale prototype biofiltration system showed volumetric productivity (i.e., average rate of gasoline degradation per unit bed volume) values that were consistent with those obtained with laboratory column biofilters at similar inlet gassline concentrations. In addition, total benzene, toluene, ethyl-benzene, and xlyene (BTEX) removal over the operating conditions employed was 50 to $55 \%$. Removal of benzene was approximately 10 to $15 \%$ and removal of the other members of the BTEX group was much higher, typically $>\$ 30 \%$.
\end{abstract}




\section{CONTENTS}

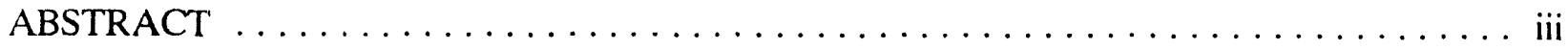

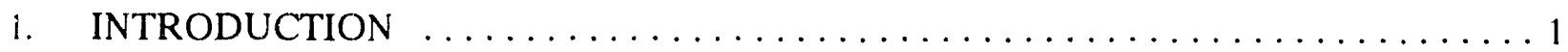

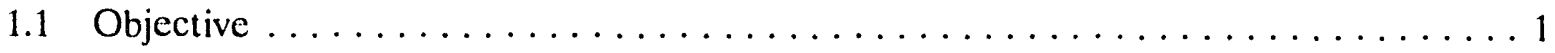

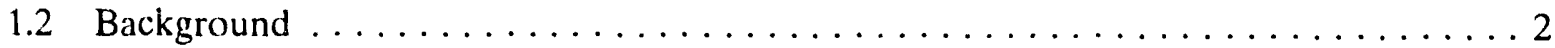

2. MATERIALS AND METHODS $\ldots \ldots \ldots \ldots \ldots \ldots \ldots \ldots \ldots \ldots \ldots \ldots$

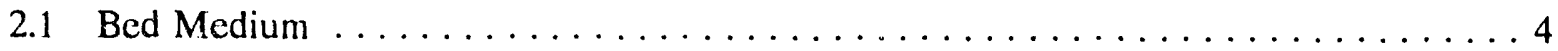

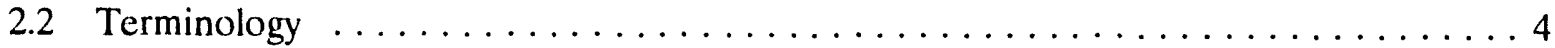

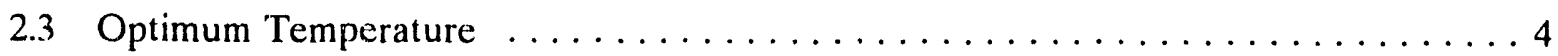

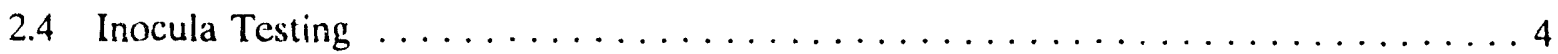

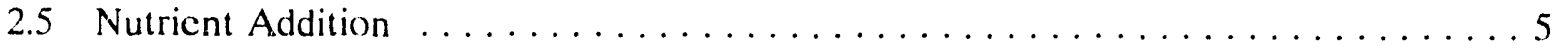

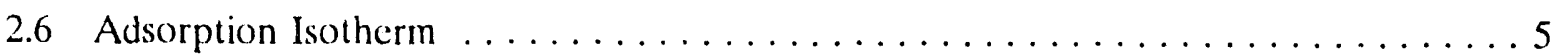

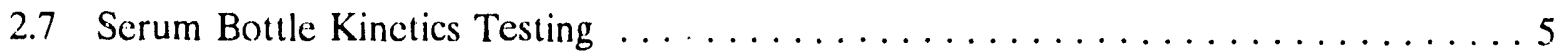

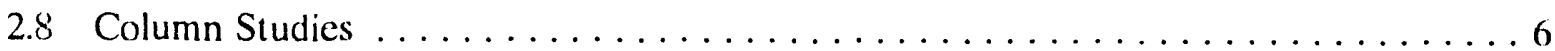

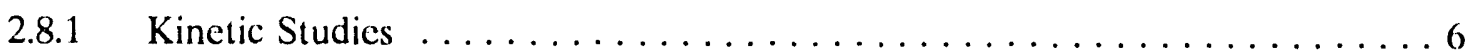

2.8.2 Bed Medium Longevity Studies $\ldots \ldots \ldots \ldots \ldots \ldots \ldots \ldots \ldots \ldots \ldots \ldots \ldots \ldots$

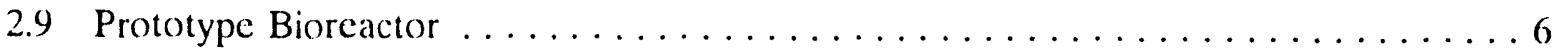

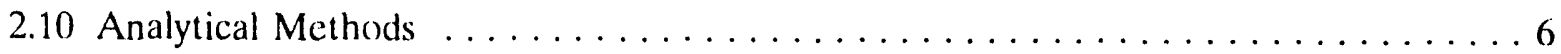

2.10.1 Serum Bottle and Column Studies $\quad \ldots \ldots \ldots \ldots \ldots \ldots \ldots \ldots$

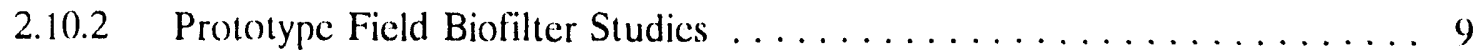

3. RESULTS AND DISCUSSION $\ldots \ldots \ldots \ldots \ldots \ldots \ldots \ldots \ldots \ldots \ldots \ldots \ldots$

5. REFERENCES ............................. 20) 


\section{FIGURES}

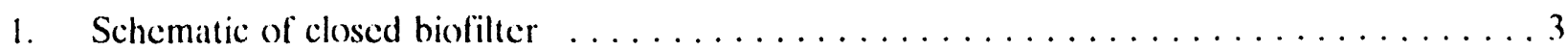

2. Schematic of vapor vacuum extraction off-gas treatment with a biofiller $\ldots \ldots \ldots \ldots$

3. Schematic of gasoline station remediation site $\ldots \ldots \ldots \ldots \ldots \ldots \ldots \ldots \ldots$

4. Schematic of prototype field biofilter $\ldots \ldots \ldots \ldots \ldots \ldots \ldots \ldots \ldots \ldots \ldots \ldots$

5. Adsorption isotherm for gasoline vapors by bed medium at $30^{\circ} \mathrm{C} \ldots \ldots \ldots \ldots \ldots$

6. Adsorption isotherm for gasoline vapors by bed medium at $4\left(0^{\circ} \mathrm{C} \ldots \ldots \ldots \ldots \ldots\right.$

7. Removal of gasoline at various concentrations by unacelimated bed medium $\ldots \ldots \ldots$ II

8. Gasoline removal comparing amended to unamended bed medium at $30^{\circ} \mathrm{C} \ldots \ldots$

9. Gasoline removal by bed medium upon repeated gasoline exposure at 3()$^{\circ} \mathrm{C} \ldots \ldots \ldots$

10. Chromatograms showing gasoline vapor component removal with time by bed medium

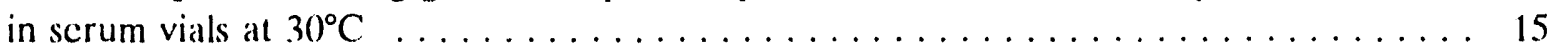

11. Volumetric productivity for gasoline removal by bed medium in serum vials at $30^{\circ} \mathrm{C} \ldots \quad 17$

12. Volumetric productivity for gasoline removal by bed medium in continuous flow

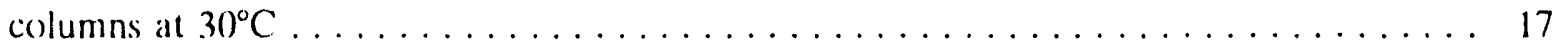

13. Biofilter hed medium longevity as a function of BTEX removal $\ldots \ldots \ldots \ldots \ldots \ldots$

14. Volumetric productivity for gasoline removal by the field scale prototype biofilter $\ldots \ldots$ is

15. Removal of total B'TEX by the prototype field biofilter $\ldots \ldots \ldots \ldots \ldots \ldots \ldots \ldots$

\section{TABLE}

1. Influence of temperature on gasoline removal rates by micro-organisms indigenous 10

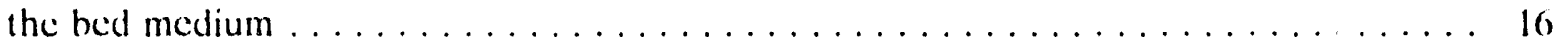




\section{Removal of Gasoline Vapors from Air Streams by Biofiltration}

\section{INTRODUCTION}

\subsection{Objective}

The U.S. Department of Energy (DOE), other government agencies, and private industries have recognized needs for treatment technologies targeting remediation of hydrocarbon contaminated subsurface soils. Vapor vacuum extraction (VVE) technologies are becoming a preferred method for remediation of this type of contamination. While effective in removing large quantities of volatile organics, such as gasoline hydrocarbons from the subsurface, VVE technologies produce an off-gas stream heavily ladened with the extracted hydrocarbons. As a result, the off-gas stream must often be treated before it can be released into the environment. Current off-gas treatment technologics consist of either sorption of the volatile vapors onto activated carbon or incineration. Both of these methods are economically unfavorable and constitute a significant portion of the operating expenses associated with a VVE system.

Biofiltration offers an alternative for the treatment of VVE off-gases. This report summarizes pertinent results from a hydrocarbon biofilter development and demonstration effort performed as a part TTP No. ID121701. "Removal and Degradation of Hydrocarbon and Halocarbon Vapors by Biofiltration." The information contained below supplements earlier information contained in a July 1992 study report ${ }^{\text {a }}$ that summarized in detail the laboratory portion of this effort.

This development and demonstration effort was performed under a Cooperative Research and Development Agreement (CRADA) with an industrial partner, EG\&G Rotron, playing a key role. The work performed under this CRADA began in March 1992 after funding was received from DOE's Office of Technology Development. The hydrocarbon biofilter demonstration phase of this project was finished in November 1992 with the successful completion of a hydrocarbon biofilter demonstration at a ficld remediation site in Reading, Massachusetts. EG\&G Rotron has already commercialized the biofilter that resulted from this project, and the first commercial production biofilter was shipped to a customer in Texas in February 1993.

Based on the successful outcome of this project, EG\&G Rotron and EG\&G Idaho, Inc./Idaho National Engineering Laboratory (INEL) have decided to continue the CRADA relationship and develop a halocarbon biofilter, which is scheduled for demonstration mid-summer of 1993.

a. Letter from W. A. Apel to D. T. Maiers, "Study Report - TTP No. ID-1217-()4, Removal and Degradation of Hydrocarbon and Halocarbon Vapors by Biofiltration," EG\&G Idaho, Inc., WAA-7692, July $31,1992$. 


\subsection{Background}

The use of gas/vapor phase-grown micro-organisms to remove organic components from gas streams is a technology currently under active development. Initial information indicates that gas/vapor phase bioreactors may be suitable for selective removal of a number of different gases and vapors from gas streams and play a major role in efficacious, cost-effective remediation of volatile pollutants from a number of different environmental media. This view is supported by the work of researchers in the United States together with the results from field applications of gas and vapor bioprocessing in Europe, particularly in Germany and the Netherlands. ${ }^{1,2,3,4,6}$ Most of these European applications have employed a particular type of gas/vapor phase bioreactor known as a biofilter.

In concept, the biofilter design is relatively simple. The biofilter consists of a filter bed within a physical eontainer, often a box or a column, that may be closed or open (see Figure 1). A gas distribution system is present to route the gas/vapor stream through the bed. The bed usually consists of a soil or soil/compost mixture that supports the growth of micro-organisms capable of metabolizing the gas or vapor to be treated. During operation, the bed is maintained in a moist but nonsaturated condition that enhances growth of the microbes and forms a thin biofilm on the surface of the bed medium allowing maximum gas transport to the bed. The gas or vapor stream to be treated is passed through the bed where the microbes present in the biofilm metabolize the gas or vapor. The end products of this metabolism are typically carbon dioxide, water, additional microbial biomass, and depending on the composition of the gas stream treated, inorganic salts.

As many as 500 biofilter applications are believed to be active in Europe." Many of these applications are directed towards odor control from a variety of sources including agriculture, food processing, slaughter houses, sewage treatment, and rendering plants. Other applications include control of volatile toxic compounds from chemical plants, coating operations, and foundries.

Biofiltration ideally complements the VVE technology, which is becoming widely accepted for the remediation of volatile contaminants from both vadose and saturated soil zones. VVE operations result in a vapor-rich off-gas stream that often requires further treatment before release into the atmosphere. This treatment typically consists of filtration of the off-gas stream through activated carbon or incineration. While effective, both of these treatments are expensive and may constitute uj) $1150 \%$ of the cost of an ongoing VVE operation. Biofiltration is an alternative VVE off-gas treatment (see Figure 2) because numerous VVE off-gas components, such as hydrocarbons and halocarbons, can be attacked and degraded microbiologically.

Hydrocarbon degradation by both pure cultures and consortia of micro-organisms is well documented. Under aerobic conditions, microbes can mincralize to $\mathrm{CO}_{2}$ essentially all hydrocarbon volatiles, including aliphaties and aromatics, following the typical Michaclis-Menton reaction kinetics. ${ }^{7.8}$ The goal of the rescarch reported in this document was $t 0$ generate the information necessary to design, construet, and operate a prototype commercial biofilter using these organisms to remove gasoline vapors from VVE olf-gas streams. 


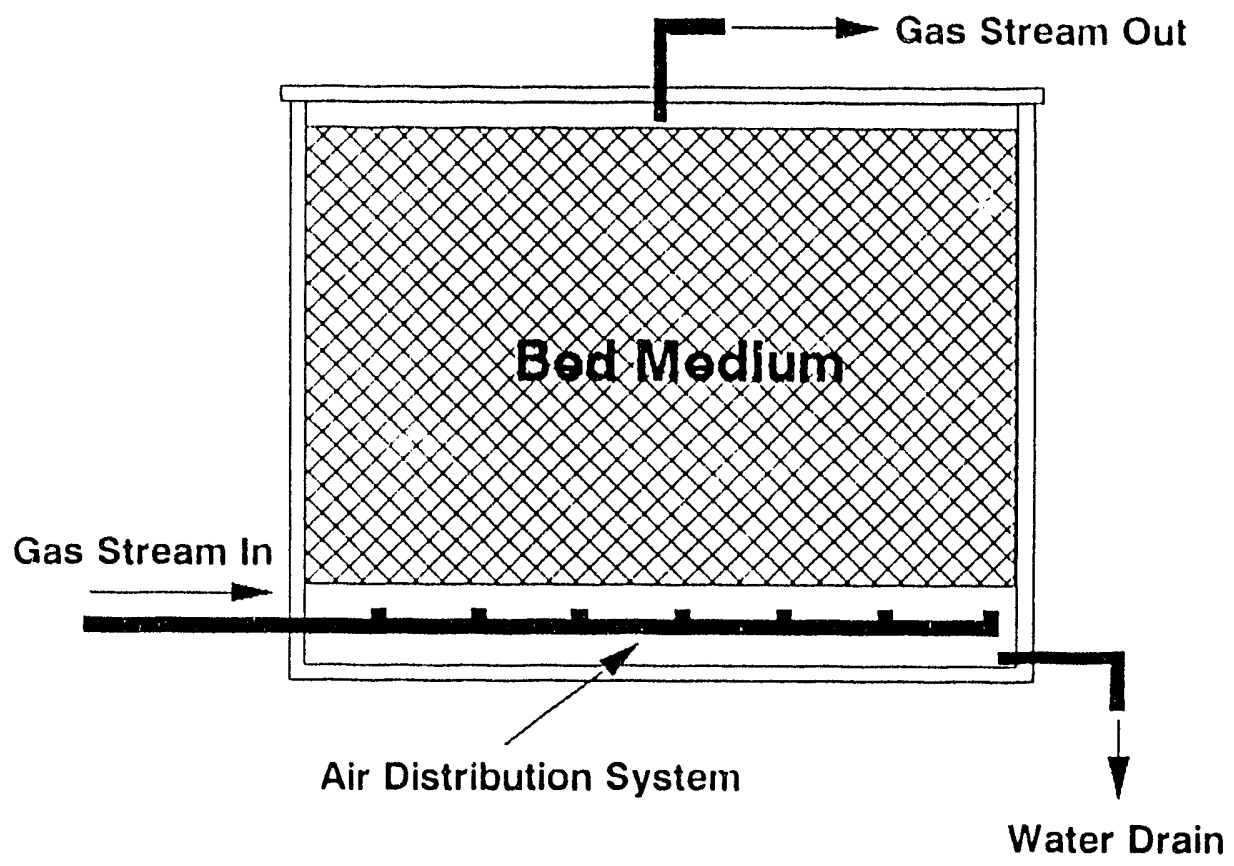

Figure 1. Schematic of closed biofilter.

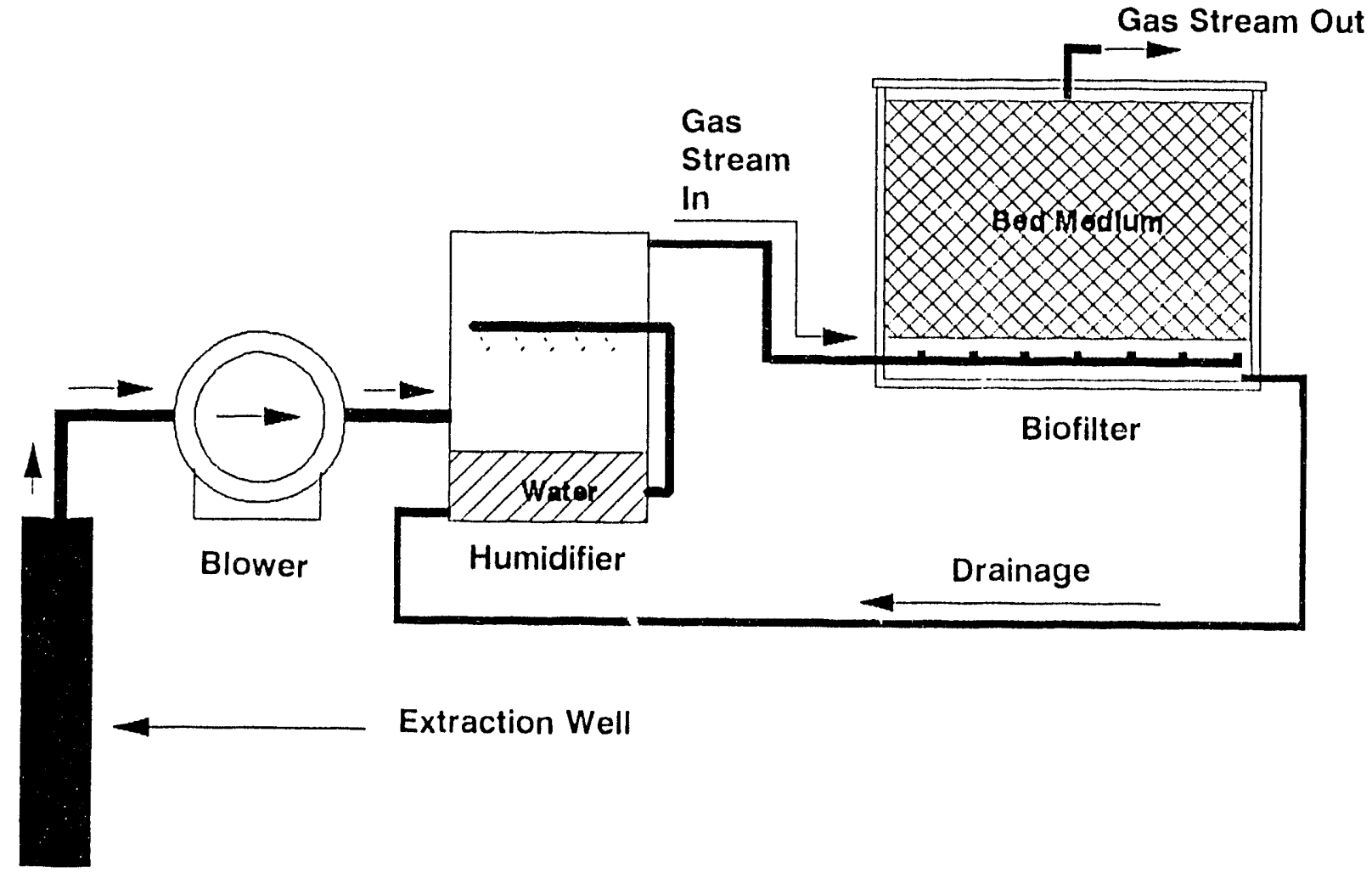

Figure 2. Schematic of vapor vacuum extraction off-gas treatment with a biofilter. 


\section{MATERIALS AND METHODS}

\subsection{Bed Medium}

The bed medium used for scrum vial and column experiments was a proprictary blend that was developed to minimize gas flow channeling while facilitating the growth of micro-organisms. In all the experiments, sufficient water was added to the bed medium blend to create a soil suction of 10 centibars as measured with a $2100 \mathrm{~F}$ Soilmoisture probe (Soilmoisture Equipment Corporation, Santa Barbara, California).

\subsection{Terminology}

Using commercial VVE terminology, gasoline vapor concentrations are reported in parts per million. Unless otherwise specified, parts per million concentrations were determined based on volume-to-volume comparisons.

\subsection{Optimum Temperature}

Four temperatures were screened for maximum gasoline vapor removal rates: $22,30,40$, and $54^{\circ} \mathrm{C}$. Five grams of bed medium were added to $120 \mathrm{~mL}$ serum bottles, and the bottles were sealed with $20 \mathrm{~mm}$ Teflon-lined rubber stoppers secured with aluminum crimp rings. Gasoline was added 10 the serum bottle headspace at a concentration of $400 \mathrm{ppm}$. Headspace samples of $1.0 \mathrm{~mL}$ were analyzed using gas chromatography (GC) for total hydrocarbon content over time. Likewise, samples of $0.25 \mathrm{~mL}$ were analyzed using GC to monitor changes in $\mathrm{O}_{2}$ and $\mathrm{CO}_{2}$ concentrations in the headspace. This and all other serum bottle experiments reported in the following sections were conducted in triplicate, and the results were averaged unless otherwise stated.

\subsection{Inocula Testing}

Two commercially available hydrocarbon degrading microbial cultures and a bed medium leachate were tested for enhancement of hydrocarbon removal in the biofilter medium. One commercial culture, Solmar L-103, was obtained from the Solmar Corporation, while another commercial culture, Tesoro PES-31, was obtained from the Tesoro Petroleum Distributing Company. The leachate was obtained from percolation of water through the bed medium. This was accomplished by filling a closed $3 \times 36$-in. glass column with bed medium and recirculating a gasolinein-air mixture through the column in an upflow direction while simultaneously circulating a water drip through the column in a downflow direction. Gasoline and oxygen levels in the recirculating gas mixture were monitored with time using GC, as described below, and a fresh gasoline-in-air mixture was reinjected into the column whenever either the gasoline or oxygen vapor concentration approached depletion. At the end of 2 weeks, leachate from the recirculating water drip was collected and used as a gasoline enrichment inoculum in subsequent experiments. All inocula were added to the bed medium as liquid cultures. Before addition, cultures were adjusted to a density of approximately $1.0 \times 10^{9}$ cells $\mathrm{mL}^{-1}$, and $0.26 \mathrm{~mL}$ of inoculum were added per gram of bed medium. The two commercial inocula were exposed to gasoline vapors for approximately 10 days before addition to the bed medium. All inocula were tested for gasoline vapor removal versus uninoculated 
controls using serum vial cultures, described in Section 2.3 , and incubated statically at $30^{\circ} \mathrm{C}$. Gasoline levels in the headspace of the serum vials were followed with time using GC analyses.

\subsection{Nutrient Addition}

A $0.5 \%$ solution of Miracle Gro fertilizer was added to the bed medium mixture to determine whether the addition of macronutrients (e.g., nitrogen, phosphorous, etc.) and trace elements had an eflect on hydrocarbon degradation. The Miracle Gro was added to the bed medium in liquid form as recommended by the manufacturer to ensure even distribution of the nutrient: The Miracle Gro-supplemented bed medium was then placed in serum vials as described in Section 2.3. Gasoline was added to the headspace, and the samples were incubated at $30^{\circ} \mathrm{C}$. Samples were analyzed using GC for hydrocarbon remaining in the headspace.

\subsection{Adsorption Isotherm}

The ability of the bed medium to sorb gasoline hydrocarbons abiotically was determined at 30) and $40^{\circ} \mathrm{C}$. At $40^{\circ} \mathrm{C}$, testing was done in a concentration range of 50 to 2,000 ppm gasoline-in-air. A concentration range from 400 to $25,000 \mathrm{ppm}$ gasoline-in-air was tested at $30^{\circ} \mathrm{C}$. The gasoline concentration in the headspace of samples at $30^{\circ} \mathrm{C}$ was monitored using GC analyses at 30,60 , and 90 minutes to determine when adsorption was complete as denoted by a decrease in the rate of hydrocarbon loss. The gasoline concentration in the headspace of the vials incubated at $40^{\circ} \mathrm{C}$ was analyzed using GC after incubation for approximately 3 hours. Indigenous microbes in the bed medium used at both temperatures had been inhibited by the addition of $500 \mu \mathrm{g} \mathrm{of} \mathrm{HgCl}_{2} \mathrm{~g}^{-1}$ of bed medium. Adsorption isotherms were generated from the resulting data using previously described standard techniques. ${ }^{9}$

\subsection{Serum Bottle Kinetics Testing}

After an optimal temperature range was determined, kinetic experiments were conducted in scrum vials using the echniques described in Section 2.3. Gasoline removal was monitored in a concentration range from 400 to $25,000 \mathrm{ppm}$ gasoline-in-air. The experiments were run at a temperature of $30^{\circ} \mathrm{C}$ and analyzed using GC for concentration of gasoline hydrocarbons in the headspace at 48 hour intervals.

Serum vial experiments were also run to determine the effect of the amendment clays on gasoline removal. The serum vials were prepared in the manner described in Section 2.3. One set of vials contained bed medium that had been amended with organophilic clays to enhance hydrocarbon sorption and physical characteristics of the bed. A second set of vials contained unamended bed medium. The experiment was run at $30^{\circ} \mathrm{C}$ and sampled approximately every 24 hours. The bed medium used for the experiments had been acclimated to gasoline before the test began. 


\subsection{Column Studies}

\subsubsection{Kinetic Studies}

Continuous tlow studies were done using 3.5-in. $\times 3$-ft glass columns containing $1.5 \mathrm{~kg}$ of the bed medium. The columns were operated in a downflow mode at a flow rate of $1,000 \mathrm{~mL} \mathrm{~min}^{-1}$. Gasoline vapor was added to the columns by sparging air through liquid gasoline that was then diluted in air using a gas proportioner. The liquid gasoline stock was regularly replaced to maintain a constant feed of the more volatile components. The resulting gasoline vapor-in-air mixture was then lied directly through the columns. The columns were operated in a concentration range from approximately 100 to $15,000 \mathrm{ppm}$ gasoline-in-air. Moisture addition was achieved by manual addition of water to the vapor stream. The columns were sampled using an automatic sampling system consisting of two 16 valve actuators connected to a three-way valve. The sample lines were $1 / 16$-in. lused silica-lined stainless steel tubing. The samples were injected into the GC using a six-way gas sampling valve equipped with a $1.0 \mathrm{~mL}$ sample loop. Samples were drawn by application of a vacuum to the sample lines.

\subsubsection{Bed Medium Longevity Studies}

Longevity of the bed medium was determined using columns that were set up and sampled in the same manner as stated in Section 2.8.1. The columns were sampled at different time periods throughout a 7 month period. The columns were operated in a concentration range from approximately 250 to $500 \mathrm{ppm}$ gasoline-in-air. Each column was monitored primarily for the percent removal of the benzene, toluene, ethyl-benzene, and xylene (BTEX) related compounds.

\subsection{Prototype Bioreactor}

Field studies with a full scale prototype biofilter were conducted at a VVE installation located at a full service gasoline station site that had been in operation since 1928 (see Figure 3). Subsurface soils and groundwaters were contaminated at this site with high gasoline levels that were found in samples taken from monitoring wells. The biofilter consisted of a skid mounted, cylindrical stecl vessel, $1.52 \mathrm{~m}$ in diameter $\times 2.13 \mathrm{~m}$ in height (see Figure 4). Five stainless steel plenums supporting $2.8 \mathrm{~m}^{3}$ of bed medium were spaced at even intervals throughout the vessel. A gas stream consisting of gasoline vapors in air was removed from the VVE well by a blower system (EG\&G Rotron, Saugerties, New York) and passed through a humidifier/flow conditioner (EG\&G Rotron, Saugerties, New York) before passage in an uptlow direction through the biofilter. Bed temperature was maintained between 25 and $35^{\circ} \mathrm{C}$. The gas stream tlow rate was $20 \mathrm{cfm}$. Inlet gasoline concentration varied from 2 to $2000 \mathrm{ppm}$ (total petroleum hydrocarbons), while inlet relative humidity varied from 3 to $100 \%$. Gasoline levels in the inlet and outlet gas streams were monitored as described below.

\subsection{Analytical Methods}

\subsubsection{Serum Bottle and Column Studies}

Headspace gasoline concentrations of the vials were determined by GC analysis using a HewletlPackard 5890 Series II GC. For data collection, the GC was connected to a Compaq Deskpro 486 


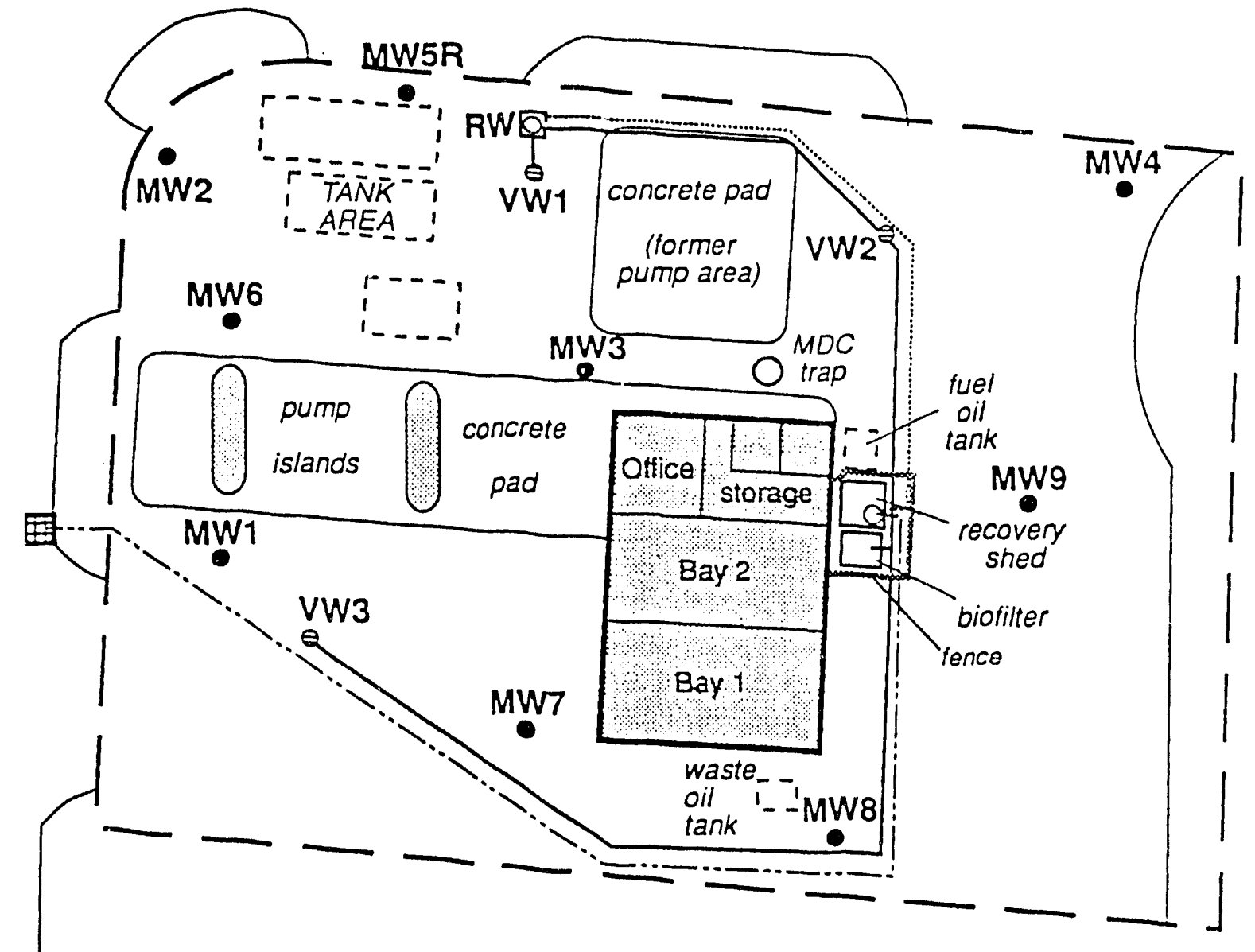

Water Influent Line
Water Eflluent Line
Soil Vapor Extraction

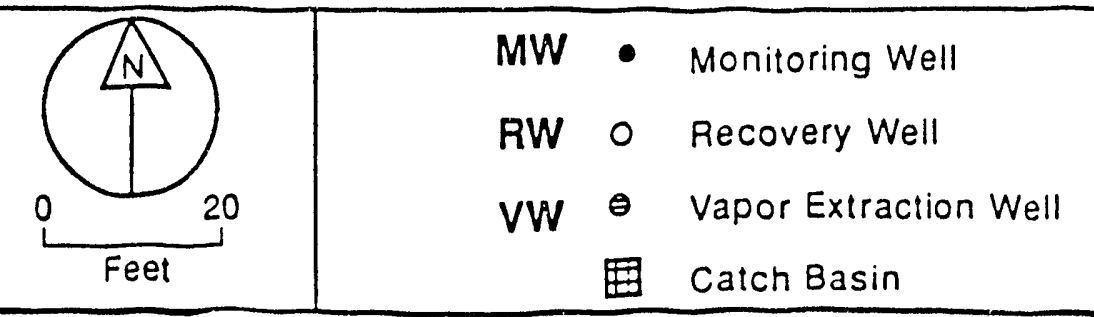

Date: 1/2/92

Revised:

Compiled by: Dratted By:

Figure 3. Schematic of gasoline station remediation site. 


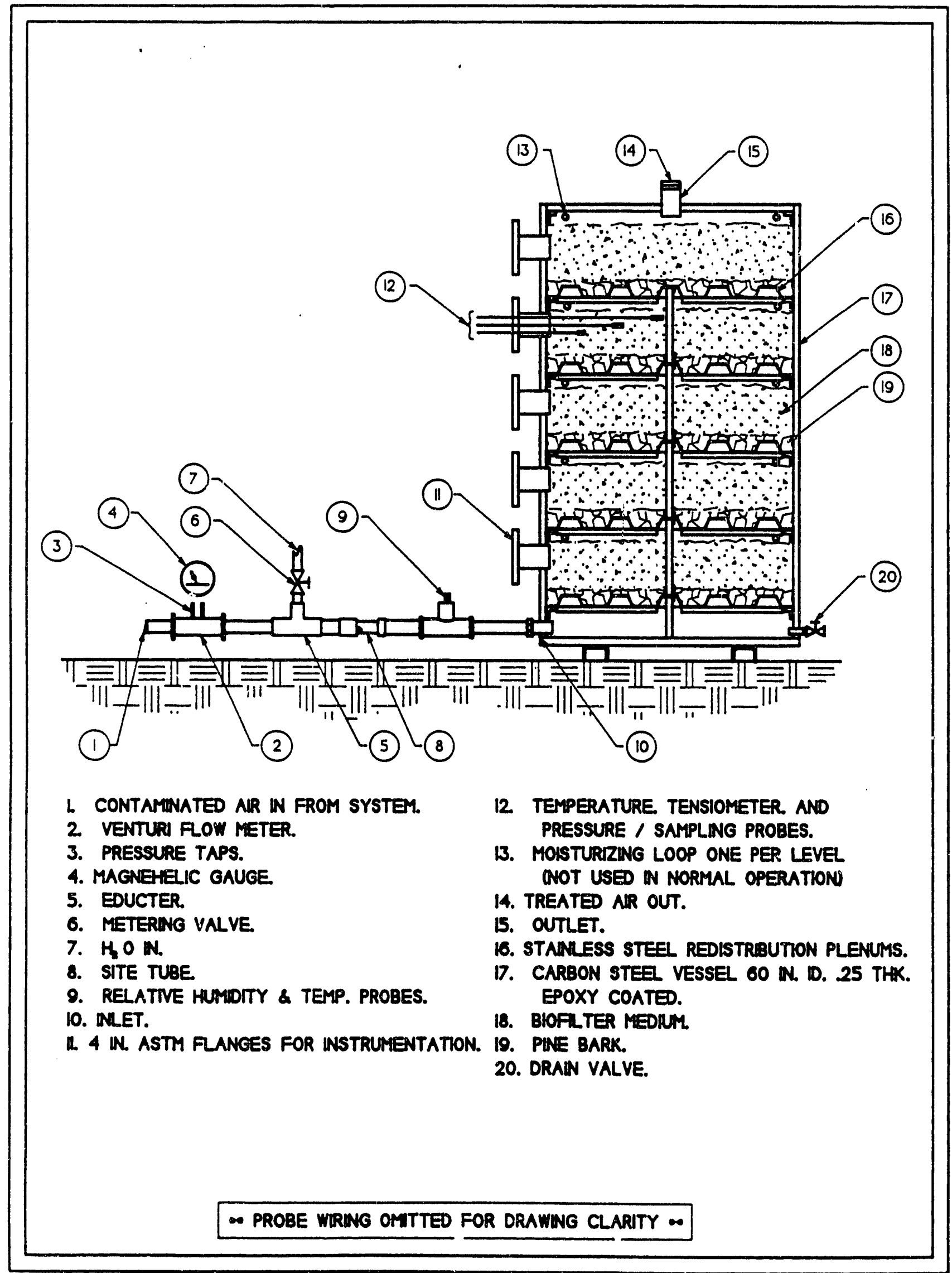

Figure 4. Schematic of prototype field biofilter. 
computer running Hewlett Packard 3365 Chemstation software. One mL samples of the vial headspace gases were injected into the GC that was equipped with a Restek $30 \mathrm{~m}, 0.32 \mathrm{~mm}$ (inside diameter). The Rtx-5 column contained a $0.25 \mu \mathrm{m}$ film thickness of crossbonded $95 \%$ dimethyl and $5 \%$ diphenyl polysiloxane. Following sample injection, the $\mathrm{GC}$ was maintained for 6 minutes at $30^{\circ} \mathrm{C}$ after which the temperature was increased to $150^{\circ} \mathrm{C}$ at a rate of $10^{\circ} \mathrm{C} \mathrm{min}^{-1}$. The injector tcmperature was $225^{\circ} \mathrm{C}$, and the flame ionization detector (FID) temperature was $275^{\circ} \mathrm{C}$. Helium was used as the carrier gas at a flow rate of $1.6 \mathrm{~mL} \mathrm{~min}^{-1}$ at a split ratio of 1:8.

Oxygen and carbon dioxide in the headspaces were analyzed using a Gow Mac Series 550P GC equipped with a thermal conductivity detector and an Alltect. CTRI column. Helium at a flow rate of $60 \mathrm{~mL} \mathrm{~min}^{-1}$ was the carrier gas, the injector and column temperatures were $30^{\circ} \mathrm{C}$.

\subsubsection{Prototype Field Biofilter Studies}

Gasoline concentrations in the inlet and outlet gas stream of the prototype biofilter were analyzed chromatographically using an EG\&G Chandler Engineering GC equipped with an FID. The $\mathrm{GC}$ was connected to a Spectrophysics SP4400 integrator. Column temperature was $80^{\circ} \mathrm{C}$ while inlet and detector temperatures were both $85^{\circ} \mathrm{C}$. The column used was a $10-\mathrm{ft} 5 \% \mathrm{SP} 1200$ and $1.75 \%$ Bentone 34 on Chromosorb W-AW 80/100. The carrier gas was $\mathrm{N}_{2}$ at a llow rate of $30 \mathrm{~mL} \mathrm{~min}^{-1}$. The unit was calibrated using Scott standards for BTEX and n-alkanes $\left(C_{1}-C_{7}\right)$. 


\section{RESULTS AND DISCUSSION}

The adsorption isotherms generated at 30 and $40^{\circ} \mathrm{C}$ with inhibited bed medium show gasoline adsorption as a function of gasoline concentration in the headspace at equilibrium. Linear sorption patterns were noted over the gasoline concentrations tested. At $30^{\circ} \mathrm{C}$, the isotherm is described by the equation of $y=1.02 \times 10^{-5} \mathrm{x}$ with an $\mathrm{R}^{2}=0.98$ (see Figure 5). At $40^{\circ} \mathrm{C}$, it is described by the equation $y=1.19 \times 10^{-5} \mathrm{x}$ with an $\mathrm{R}^{2}=0.99$ (see Figure 6). These data indicate that in the absence of microbial activity, the bed medium has a appreciable gasoline sorptive capacity and by itself can remove significant amounts of gasoline vapors from gasoline/air mixtures. Over the gasoline concentration range tested, gasoline sorption increased as a fuiction of gasoline concentration in the headspace with approximately $60 \mu \mathrm{g}$ of gasoline being adsorbed per gram of bed medium at a $5 \mathrm{~g}$ $\left(\mathrm{m}^{3}\right)^{-1}$ gasoline concentration in the headspace at $40^{\circ} \mathrm{C}$. The sorption rates appeared to be comparable at both temperatures and would not be expected to vary significantly over the temperature range employed in these experiments or that anticipated with the field biofilters to be tested.

Gasoline vapor removal as depicted in Figure 7 further illustrates the sorptive capacity of the bed medium. Over the gasoline concentrations tested, an initial sharp decrease in headspace gasoline levels was observed. It is hypothesized that this initial decrease was due primarily to adsorption working in conjunction with biodegradation, after which a more gradual, prolonged decrease in headspace gasoline levels was noted. This gradual decrease was believed to primarily correspond to biodegradation of the gasoline by microbes indigenous to the bed medium because corresponding gasoline loss in control vials was negligible. Studies with fresh bed medium showed $>10^{6}$ colony

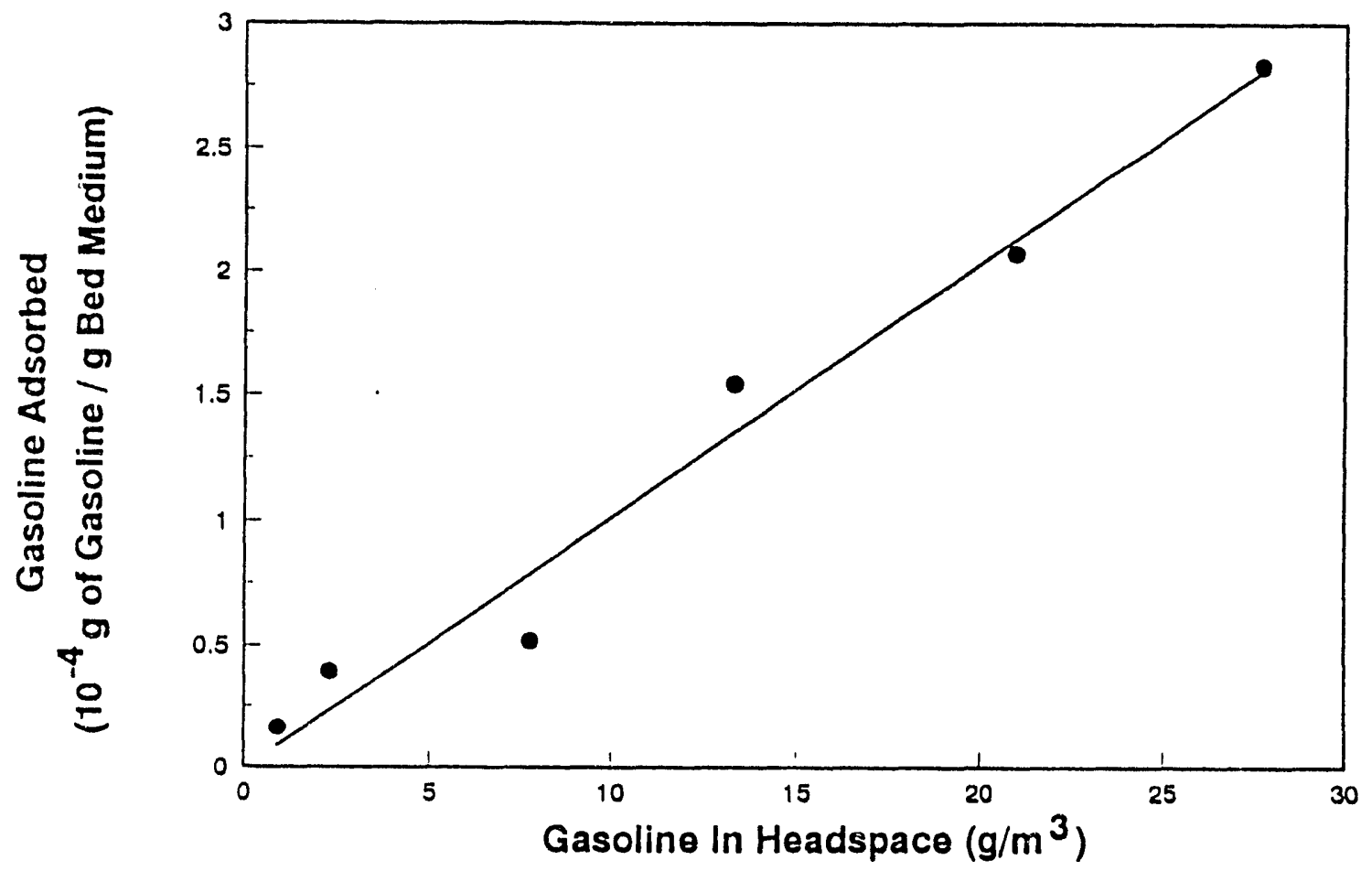

Figure 5. Adsorption isotherm for gasoline vapors by bed medium at $30^{\circ} \mathrm{C}$. 


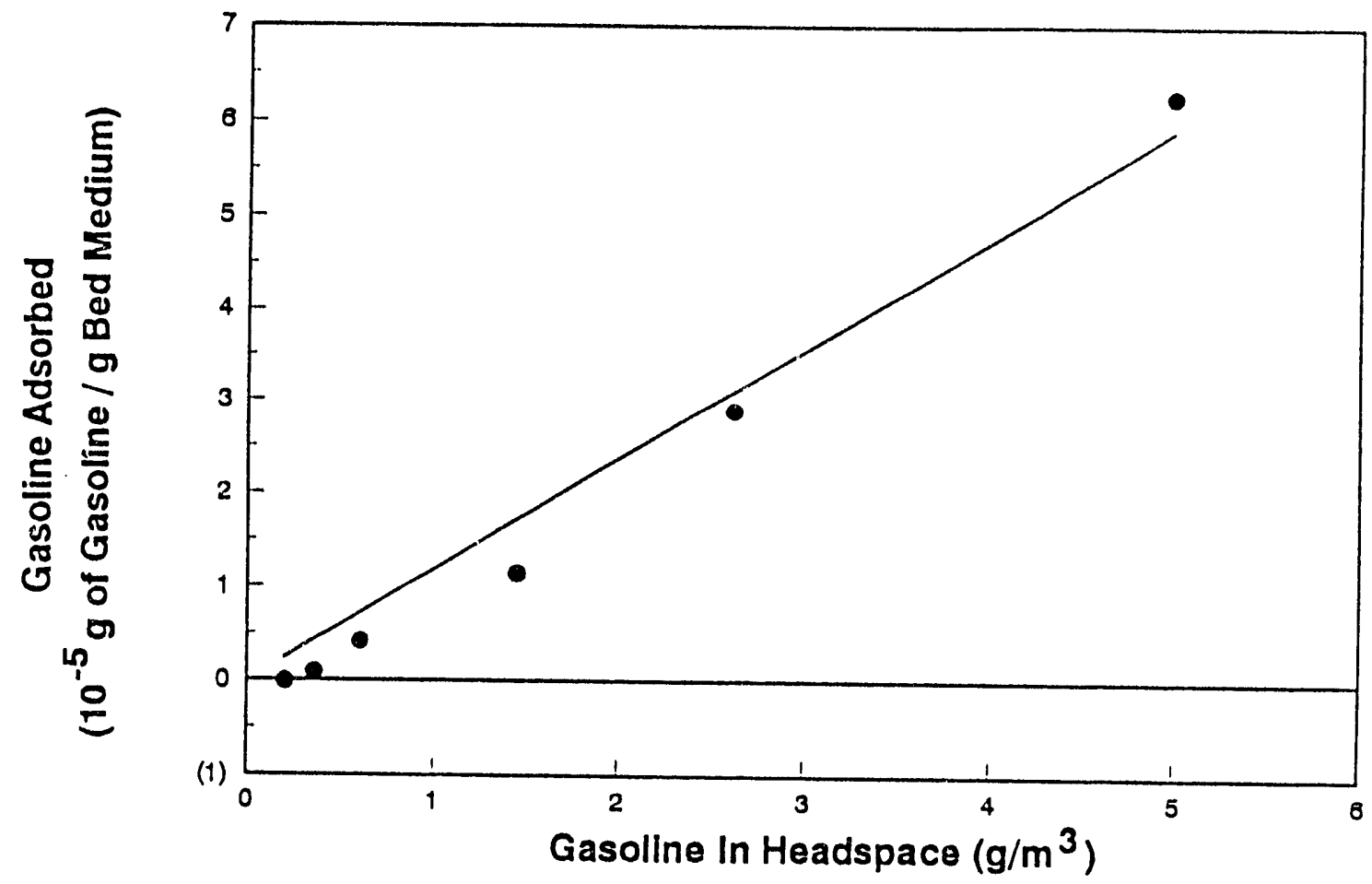

Figure 6. Adsorption isotherm for gasoline vapors by bed medium at $40^{\circ} \mathrm{C}$.

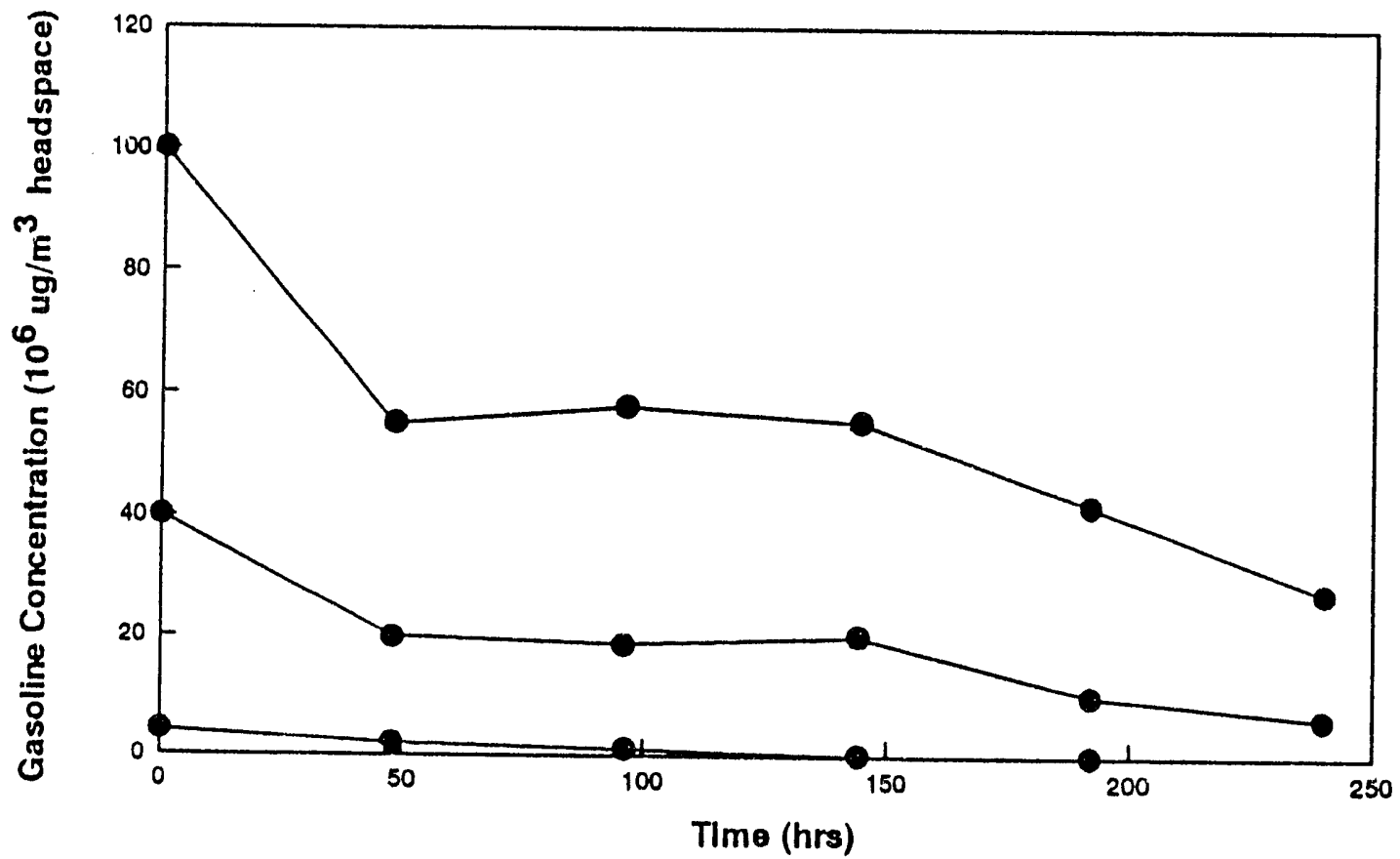

Figure 7. Removal of gasoline at various concentrations by unacclimated bed medium. 
forming units per gram that were capable of growing in a gasoline atmosphere on agar mineral salts plates. This bed medium appeared to have an adequate indigenous gassoline degrading microbial population so that an exogenous inoculum was not required for gasoline degradation.

The effects of clay amendments on gasoline removal rates in serum vials are shown in Figure 8. Overali gasoline removal was shown to be slightly inhibited by the addition of the amendments. In general, BTEX removal by the compost was not affected by the addition of the amendments. Virtually $100 \%$ of all BTEX compounds were removed within the first 24 hours, with the exception of benzene, of which approximately $95 \%$ was removed. The organophilic clays did inhibit removal of the light chain hydrocarbons found in gasoline.

In similar column experiments comparing amended and unamended compost based bed medium, light chain removal in the unamended columns was superior to that observed for the amended bed medium during the initial phase of the experiment. However, after approximately 14 days $0 . "$ exposure to gasoline, the light chain removal in the unamended column began to drop, eventually becoming similar to that exhibited by the amended column. Light chain removal in the amended column showed no appreciable changes during the entire test period. No differences were noted in BTEX removal for both amended and unamended bed medium.

Studies with fertilizer-supplemented bed medium revealed no detectable increase in microbial activity. These studies were performed with fresh bed medium, and further studies will be conducted to determine whether fertilizer supplementation has a positive influence on microbial removal rates of aged bed medium that may be depleted of some essential nutrients.

Experiments conducted with bed medium inoculated with two commercial consortia of hydrocarbon degrading microbes and an INEL consortium of hydrocarbon degrading microbes confirmed that no inoculation is necessary. The bed medium inoculated with these three exogenous inocula showed no increase in degradation rates versus uninoculated bed medium containing only indigenous microbes. This confirms that no inoculation is necessary upon start up due to the substantial levels of hydrocarbon degrading bacteria naturally contained in the bed medium. In a commercial bioremediation application, this is significant because culturing and addition of a stabie, exogenous, gasoline degrading inoculum could be a significant complication during start up and could add appreciable expense and uncertainty to the operation.

Figure 9 supports this view and illustrates that within approximately 2 weeks, the bed medium can become further acclimated to gasoline vapors with a significant increase in gasoline degradation rates occurring after this acclimation period. After exposure for 2 wecks to $400 \mathrm{ppm}$ gasoline in air, respiking of the same bed medium-containing vials with similar gasoline-in-air concentrations results in significantly increased (i.c.. four times) gasoline vapor removal rates. Subsequent respikes do not lead to appreciably more rapid gasoline removal rates, and as a result, the bed medium appears to be fully conditioned to provide the most rapid rates of gasoline removal achievable after the initial 2 week conditioning period. This effect is believed to be the direct result of an increased population of gasoline degrading micr()-organisms present in the bed medium after the 2 weck initial exposure period and has been demonstrated previously in soil microbial populations that become adapted to organic vapors. ${ }^{10}$ 


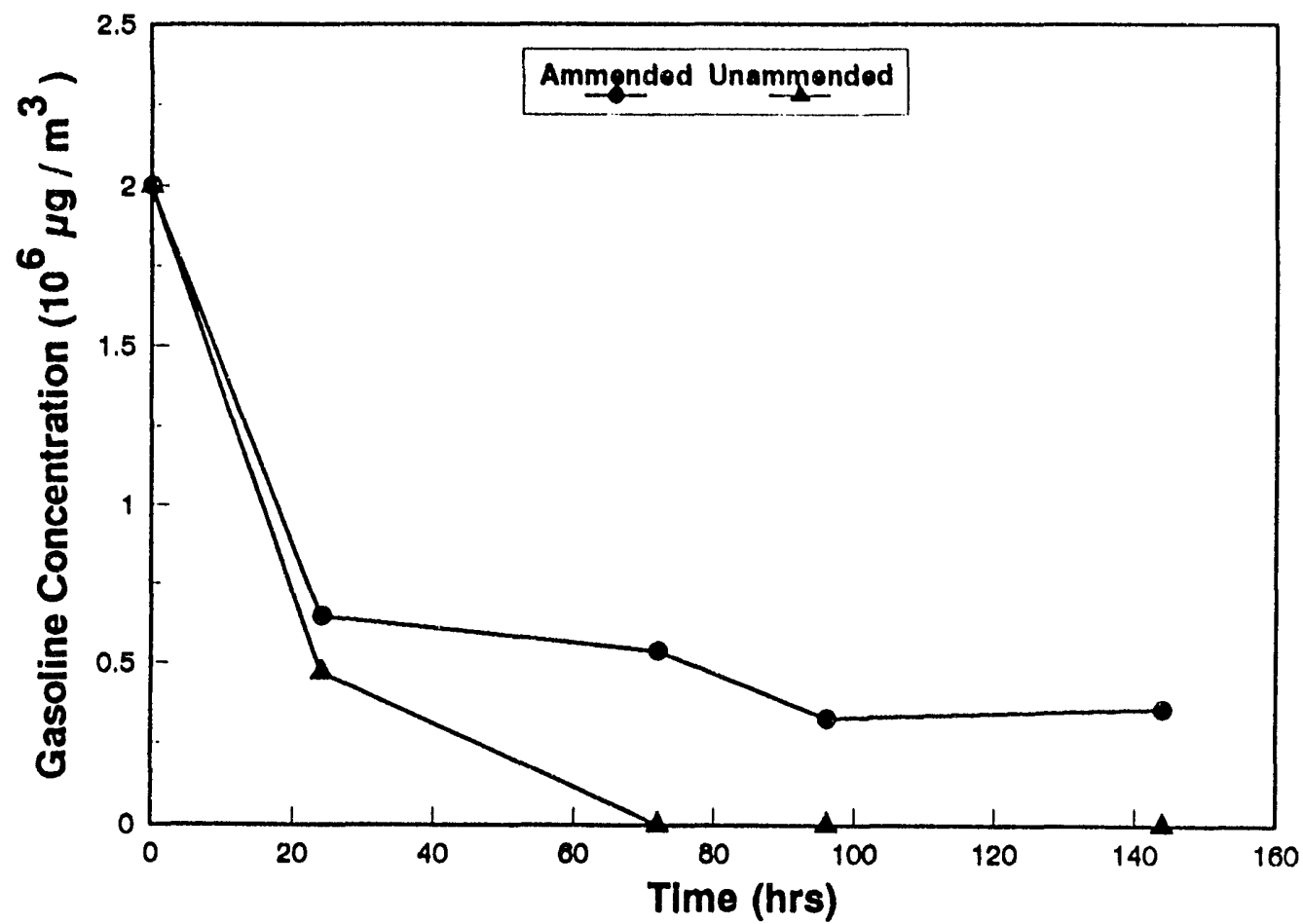

Figure 8. Gasoline removal comparing amended to unamended bed medium at $30^{\circ} \mathrm{C}$.

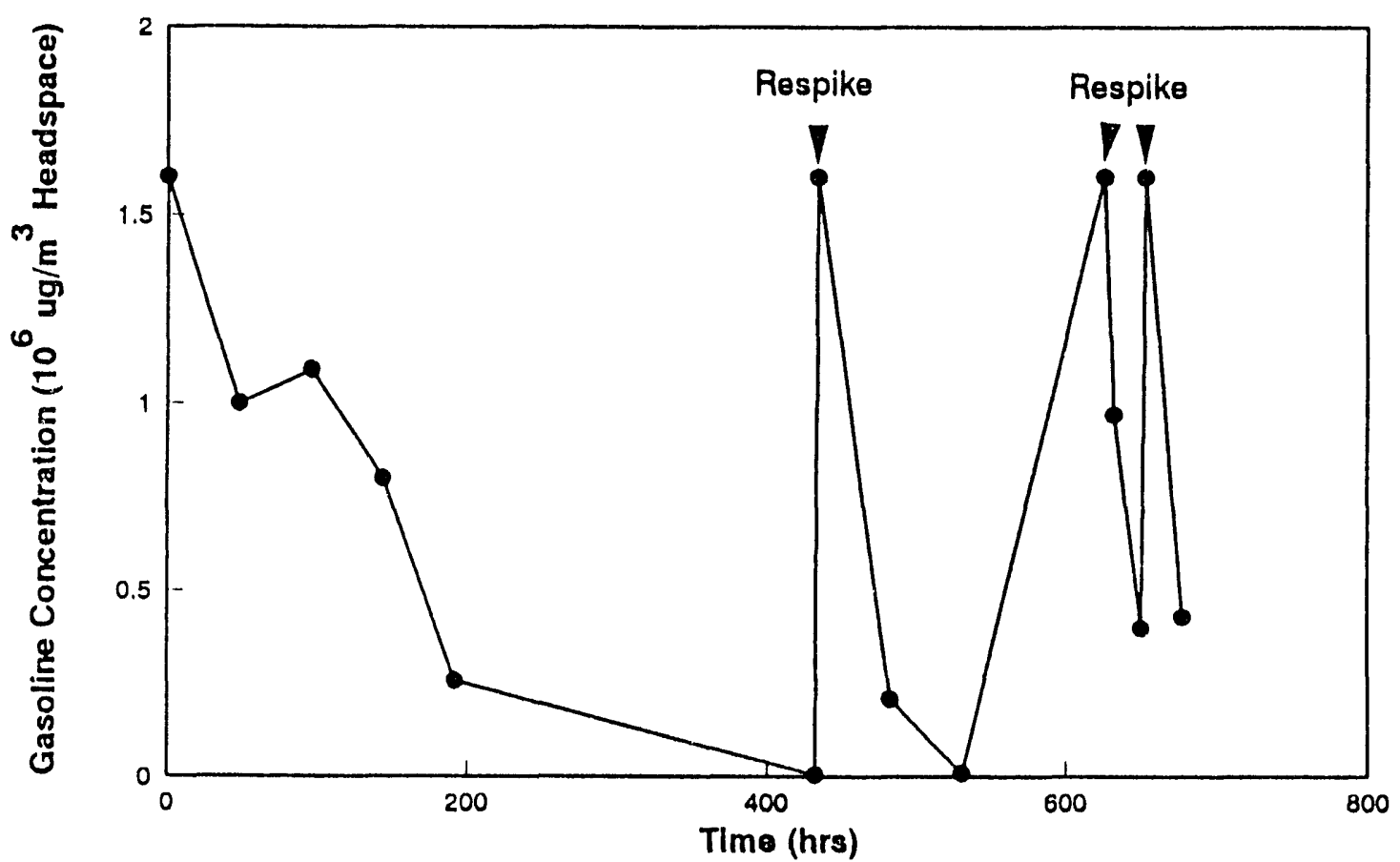

Figure 9. Gasoline removal by bed medium upon repeated gasoline exposure at $30^{\circ} \mathrm{C}$. 
These data indicate that during startup of a biofilter under lield conditions, a significant amount of gasoline removal should be noted initially both from adsorption and biodegradation, with removal rates potentially increasing for a period of days $t o$ weeks following startup. As a result, it may be possible to establish a relatively low gasoline leed rate during the startup/conditioning phase and after conditioning, to increase this feed rate four to five times without any loss in gasoline removal efficacy. This concept needs to be further tested in the field-scale biofilter to ascertain how rapidly the conditioning occurs in a full-sized biofilter operated under field conditions.

Figure 10 shows gas chromatograms illustrating removal and degradation of various gasoline components by biofiltration using the bed medium in serum vials. In general, with the analytical method employed (see Section 2), higher molecular weight fractions of the gasoline vapor appear at longer retention times on the gas chromatograms shown. In the serum vial batch systems, it is clear that biofiltration tends 10 remove the higher molecular weight constituents more quickly than the lower molecular weight constituents. The BTEX (i.e., benzene, toluene, ethylbenzene, and xylene) components were removed in a relatively rapid fashion with benzene being more recalcitrant to removal than the other members of this group. Based on the physical properties of the bed medium, it is reasonable to hypothesize that this differential removal of gasoline components is a property of the sorptive nature of the blend and subsequent degradation by the micro-organisms as opposed to a physiological inability of the microbes to metabolize the lower molecular weight components. This suggests that to rapidly remove the lower molecular weight and more volatile gasoline components, either additional exposure time or a modified bed medium with greater sorptive properties will be necessary.

Temperature studies showed that micro-organisms indigenous to the bed medium actively degrade gasoline vapors over a 22 to $40^{\circ} \mathrm{C}$ temperature range (see Table 1). There was very little difference in observed gasoline degradation rates over this range; however, no degradation was observed at $54^{\circ} \mathrm{C}$. From a practical standpoint, these data are encouraging when considering the operation of a gasoline vapor biofilter in the field because the 22 to $40^{\circ} \mathrm{C}$ temperature range more than encompasses the operating temperature range anticipated under field conditions. As such, the biofilter is expected to be robust relative to anticipated temperature fluctuations, and as a result, operating temperature should not be a factor requiring rigid control during lield operation.

When considering biofilter sizing for field applications, it is pertinent to calculate the volumetric productivity of the biofilter at the substrate concentrations that will be encountered under actual operating conditions. This information in turn can be used 10 size the biofilter as a function of substrate feed rate. The volumetric productivity values obtained in serum vial experiments over a range of gasoline concentrations encompassing those expected to be encountered in actual field applications are shown in Figure 11. Similar data for the columns run at a flow rate of $1,000 \mathrm{~mL}$ $\min ^{-1}$ and are shown in Figure 12. The $1,000 \mathrm{~mL} \mathrm{~min}^{-1}$ flow rate was chosen because in the column syslem used; it mimics the superficial gas feed velocities desired in actual field applications. In the column experiments, at a relatively high gasoline concentration $\left[\right.$ e.g., $65 \mathrm{~g}$ gasoline $\left(\mathrm{m}^{3}\right.$ of inlet gas stream $)^{-1}$, the volumetric productivity is approximately $1200 \mathrm{~g}_{\text {gasoline }}\left(\mathrm{m}^{3} \text { bed medium }\right)^{-1} \mathrm{~h}^{-1}$.

Extended performance of the bed medium is shown in Figure 13 as a function of BTEX removal. After 1 month of operation, toluene and xylene removal is at the maximum, but the microorganisms are not yet removing the benzene. Overall removal of BTEX appears to reach a maximum of approximately $62 \%$ after 4 months and then levels off at approximately $50 \%$ removal at month 

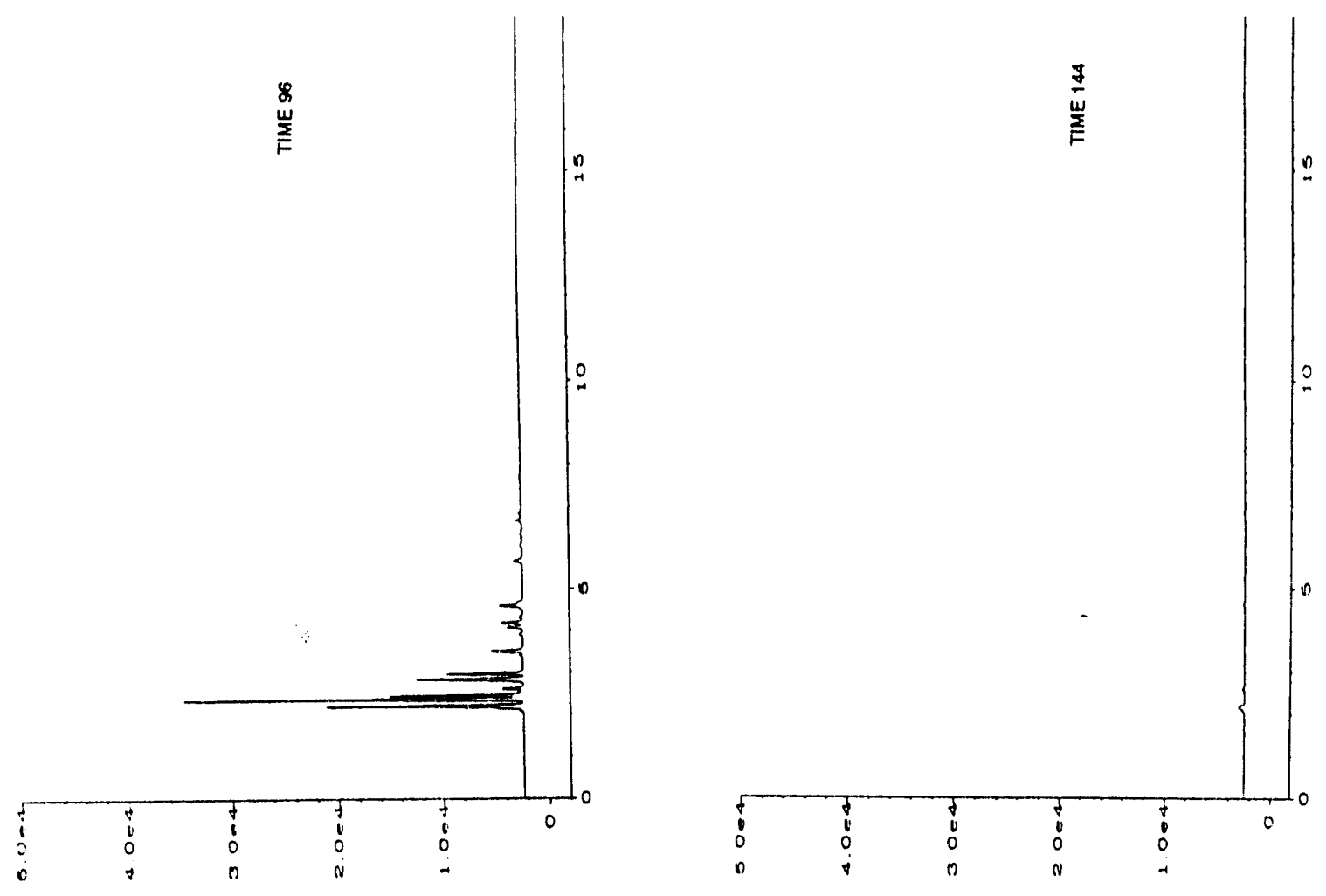

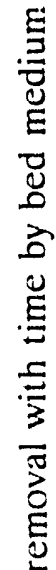
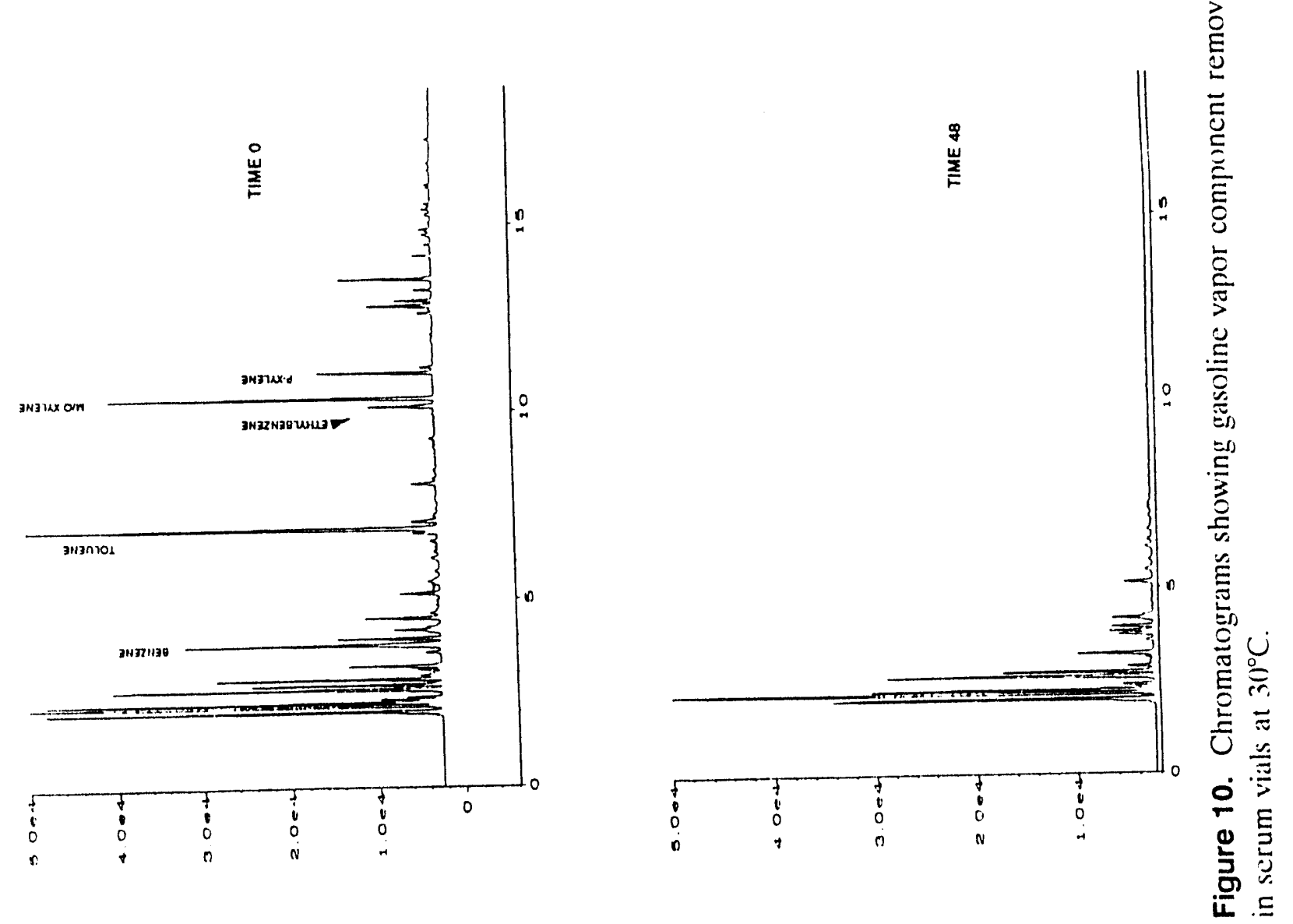
Table 1. Influence of temperature on gasoline removal rates by micro-organisms indigenous $t$ () the bed medium.

\begin{tabular}{cc}
\hline $\begin{array}{c}\text { Temperature } \\
\left({ }^{\circ} \mathrm{C}\right)\end{array}$ & $\begin{array}{c}\text { Gasoline removal } \\
\left|\mu \mathrm{g}\left(\mathrm{m}^{3}\right)^{-1} \mathrm{~h}^{-1}\right|\end{array}$ \\
\hline 22 & $7.1 \times 10^{3}$ \\
30 & $7.6 \times 10^{3}$ \\
40 & $6.3 \times 10^{3}$ \\
54 & None detected \\
\hline
\end{tabular}

seven. After 6 months of operation, the xylene removal has dropped to near $70 \%$. The lact that the bed medium shows significant removal after 7 months of exposure to gasoline is promising. A biofilter that requires low maintenance during an extended VVE remediation operation will be very cost effective. Typical maintenance of a bed medium that loses degradative ability after a short time period would be complete bed medium replacement or addition of inorganic nutrients.

Data from the field scale prototype biofilter are similar to the results obtained in the laboratory. Figure 14 shows hydrocarbon removal in terms of volumetric productivity. These data represent the lower end of the inlet gasoline concentrations tested in the laboratory, but volumetric productivity values are comparable to those obtained with the continuous flow laboratory columns at similar inlet concentrations.

Figure 15 depicts total BTEX removal as a function of BTEX inlet flow rate. These data show that under the operating conditions employed, approximately 50 to $55 \%$ of the BTEX compounds were removed. However, removal of toluene, ethylbenzene, and xylene were typically $>80 \%$ while benzene, as predicted by the laboratory data, exhibited much lower removal rates of 10 to $15 \%$.

The reaction rates of the biofilter systems tested at lower gasoline concentrations are probably considerably below those theoretically achievable due to substrate (i.e., gasoline vapor) limitations versus limitation related to insufficient microbial activity. The volumetric productivity data strongly indicate that to increase the reaction rates at working (i.e., lower) gasoline eoncentrations, optimization of biofilter design and/or the composition of the bed medium to increase contact between the gas stream and microbes may be necessary. If the biofilter design/bed medium composition can be optimized while maintaining current or even higher levels of biological activity per unit bed volume, the gasoline removal rates could be substantially increased. Clearly, however, the first step to achieving increased gasoline removal rates is to develop a biofilter system in which increased gasoline transport to the microbes takes place. 


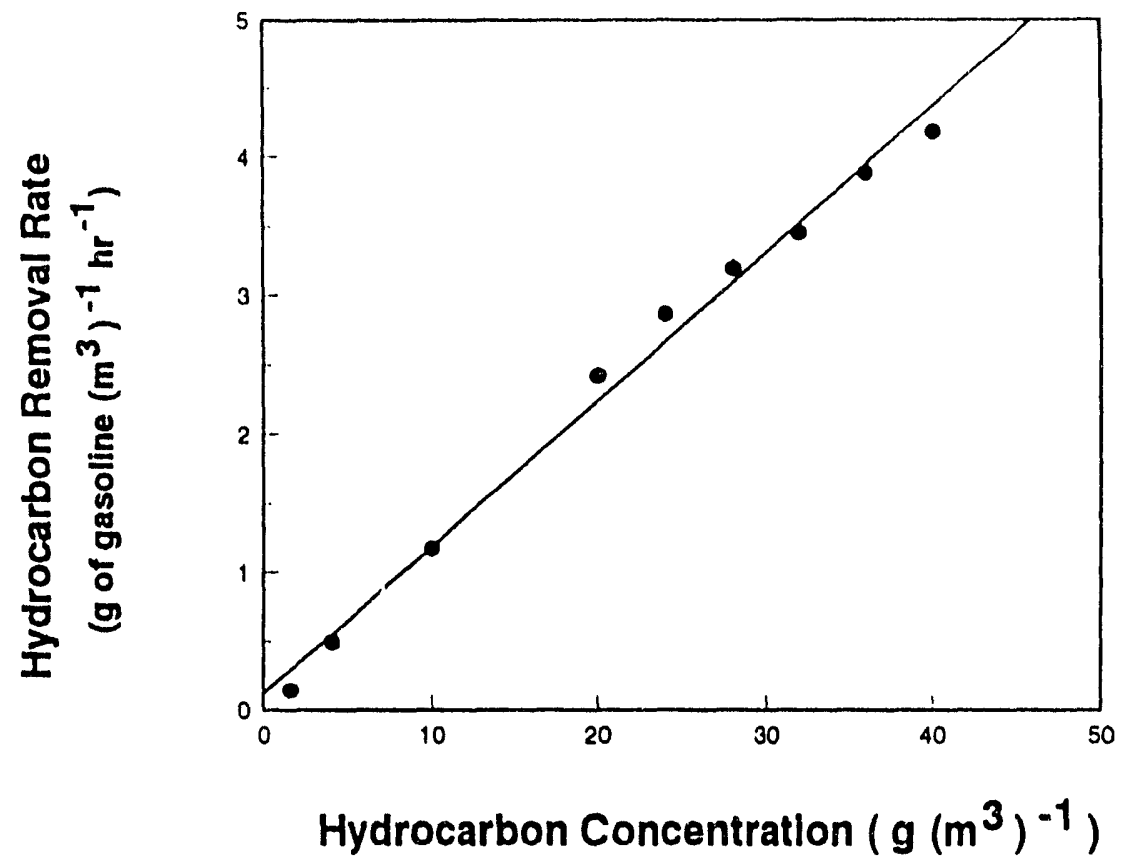

Figure 11 . Volumetric productivity for gasoline removal by bed medium in serum vials at $30^{\circ} \mathrm{C}$.

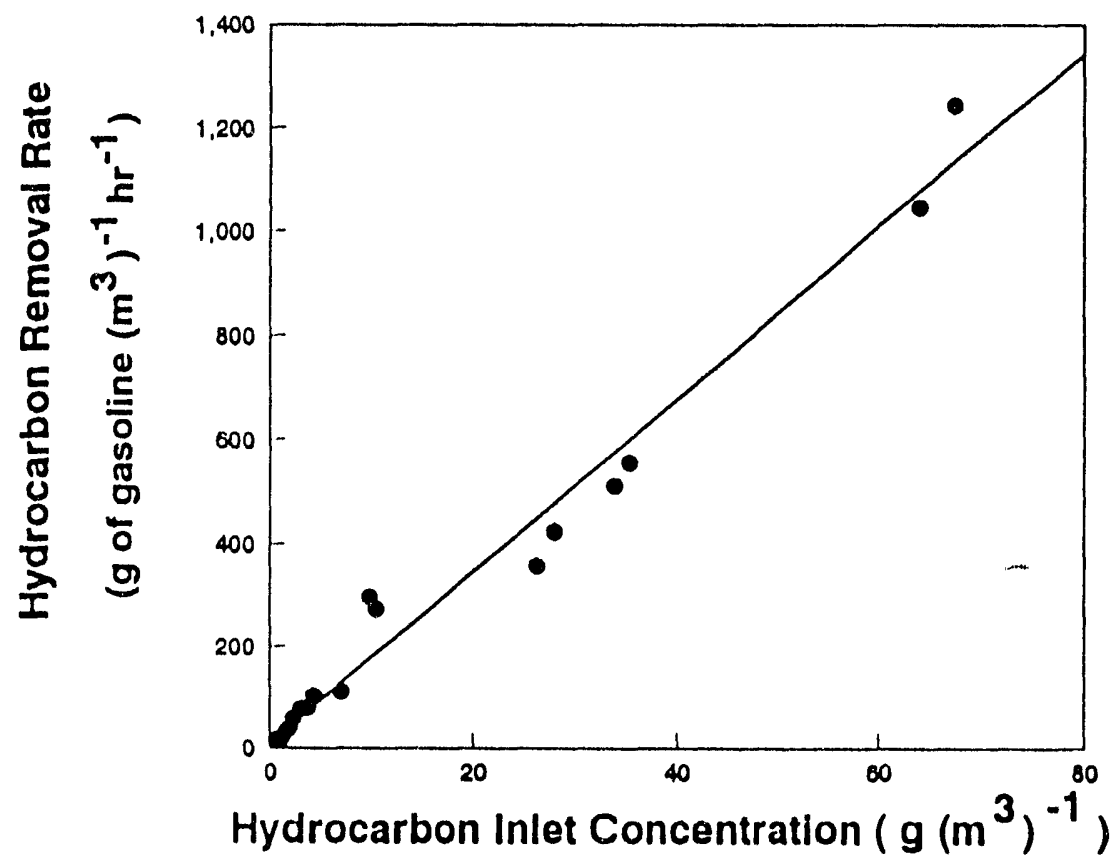

Figure 12. Volumetric productivity for gasoline removal by bed medium in continuous flow columns at $30^{\circ} \mathrm{C}$. 


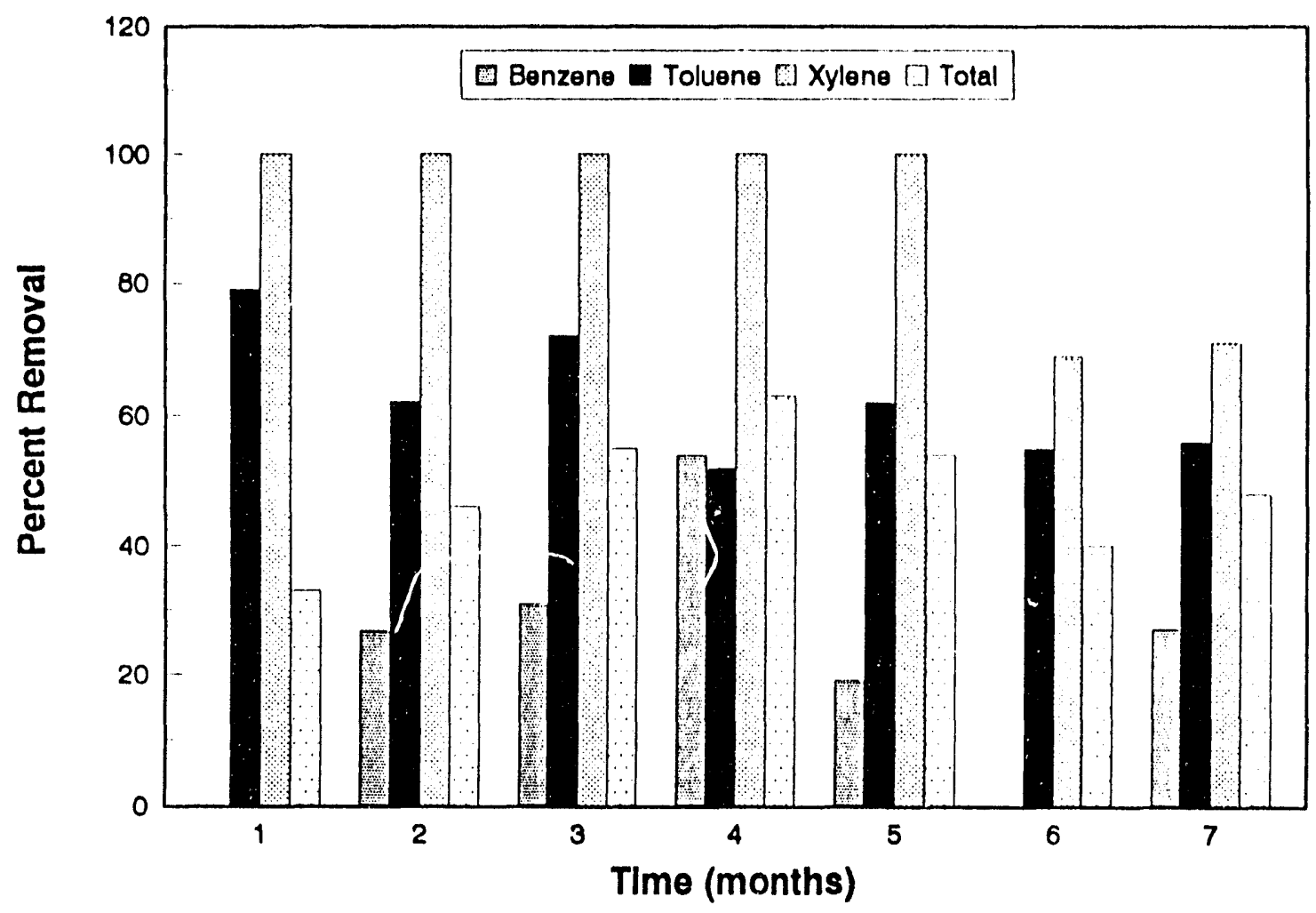

Figure 13. Biofilter bed medium longevity as a function of BTEX removal.

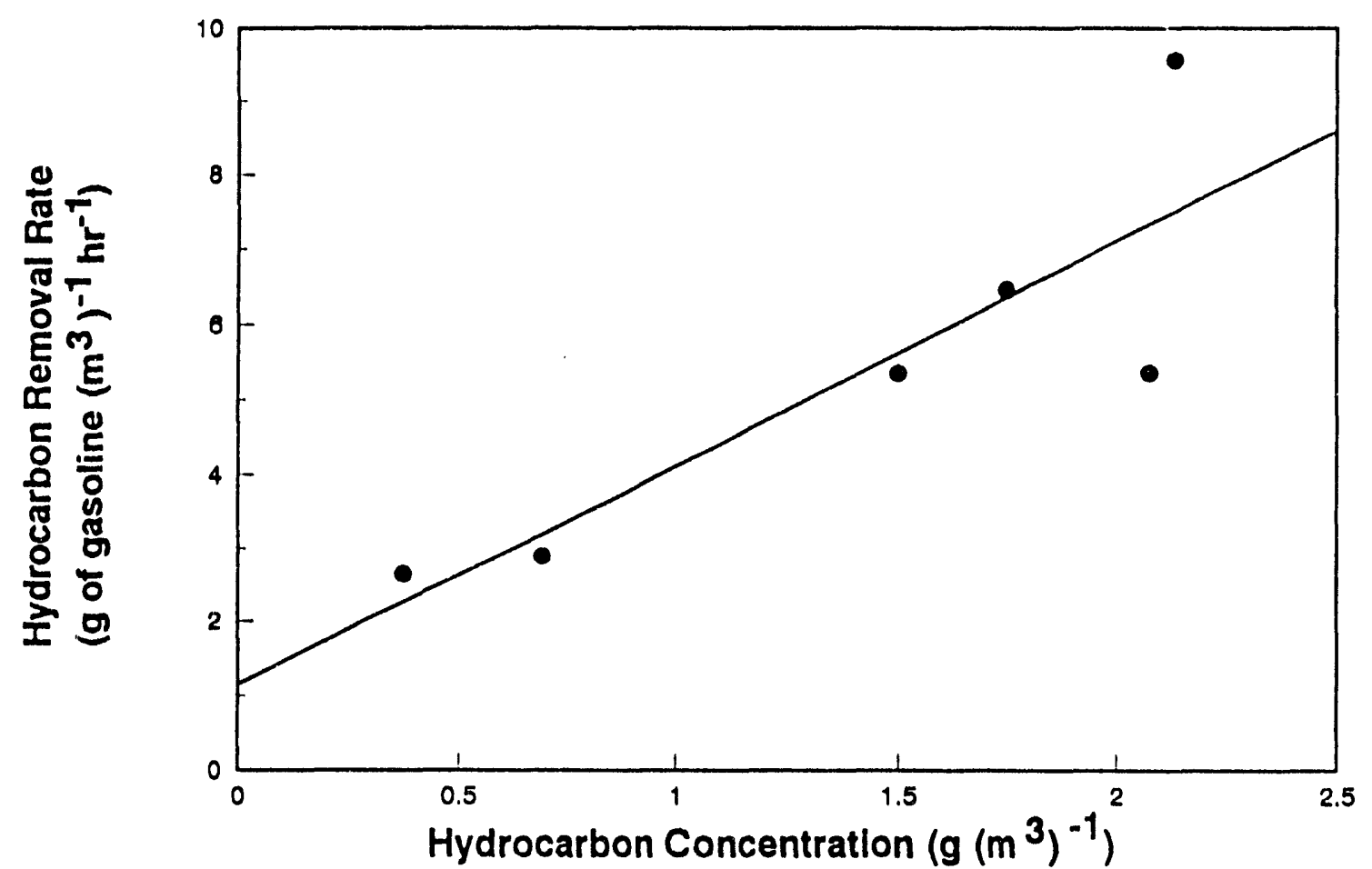

Figure 14. Volumetric productivity for gasoline removal by the field scale prototype biofilter. 


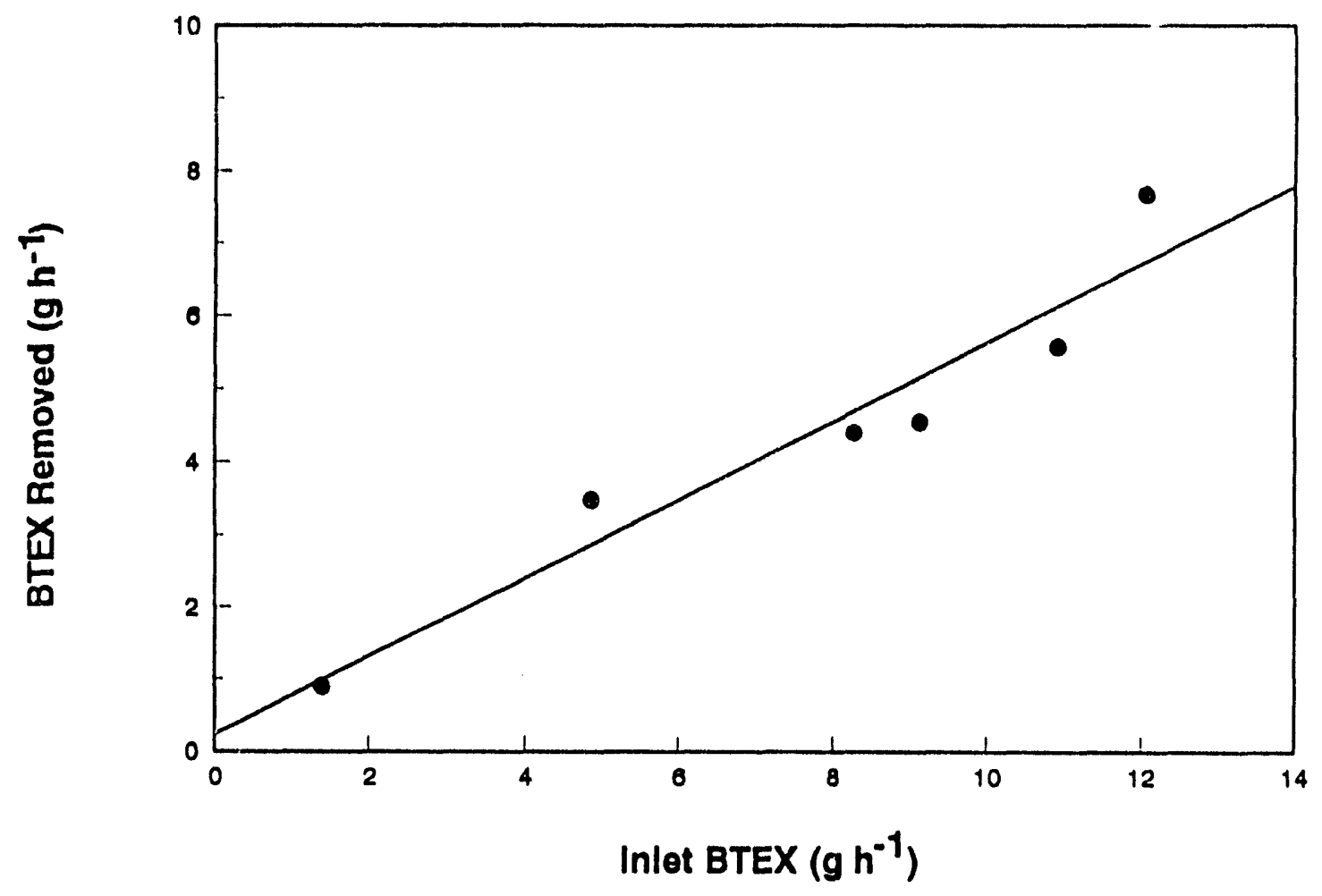

Figure 15. Removal of total BTEX by the prototype field biofilter. 


\section{REFERENCES}

1. W. A. Apel, P. R. Dugan, M. R. Wicbe, "Use of Methanotrophic Bacteria in Gas Phase Bioreactors to Abate Methane in Coal Mine Atmospheres," FUEL, 70, 1991, pp. 1001-1003.

2. W. A. Apel, P. R. Dugan, M. R. Wiebe, "Influence of Kaolin on Methane Oxidation by Methylomonas methanica in Gas Phase Bioreactors," FUEL, 71, 1992, pp. 805-808.

3. W. A. Apel, P. R. Dugan, M. R. Wiebe, E. G. Johnson, J. H. Wolfram, and R. D. Rogers, "Bioprocessing of the Environmentally Significant Gases and Vapors: Methane, Trichloroethylene, and Xylene using Gas Phase Bioreactors," ACS Symp. Series, in press, 1993.

4. H. L. Bohn, "Soil and Compost Filters of Malodorous Gases," J. Air Poll Control Assoc. 25, 1975, p. 953.

5. D. H. Kampbell. J. T. Wilson, H. W. Read, T. T. Stockdale, J. Air. Poll. Control Fed. 37, 1987, p. 1236.

6. G. Leson and A. M. Winer, "Biofiltration: An Innovative Air Pollution Control Technology for VOC Emissions," J. Air Waste Manage. Assoc. 41, 1991, pp. 1045-1054.

7. R. S. Boethling and M. Alexander, "Effect of Concentration of Organic Chemicals on their Biodegradation by Natural Microbial Communities," Appl. Environ. Microbiol, 37, 1979, pp. $1211-1216$.

8. J. G. Leahy and R. R. Colwell, "Microbial Degradation of Hydrocarbons in the Environment," Microbiol Rev. 54, 1990. pp. 305-315.

9. R. H. Perry and C. H. Chilton, Chemical Engineers' Handbook. 5th ed., McGraw-Hill Book Co., New York, New York, 1973, pp. 16-12-16-18.

10. C. W. English and R. C. Loehr, "Removal of Organic Vapors in Unsaturated Soil," Proceedings of Conference on Petroleum Hydrocarbons and Organic Chemicals in Groundwater: Prevention, Detection and Restoration. Special Issue of Groundwater Management, National Well Water Association, 1990, pp. 297-308. 

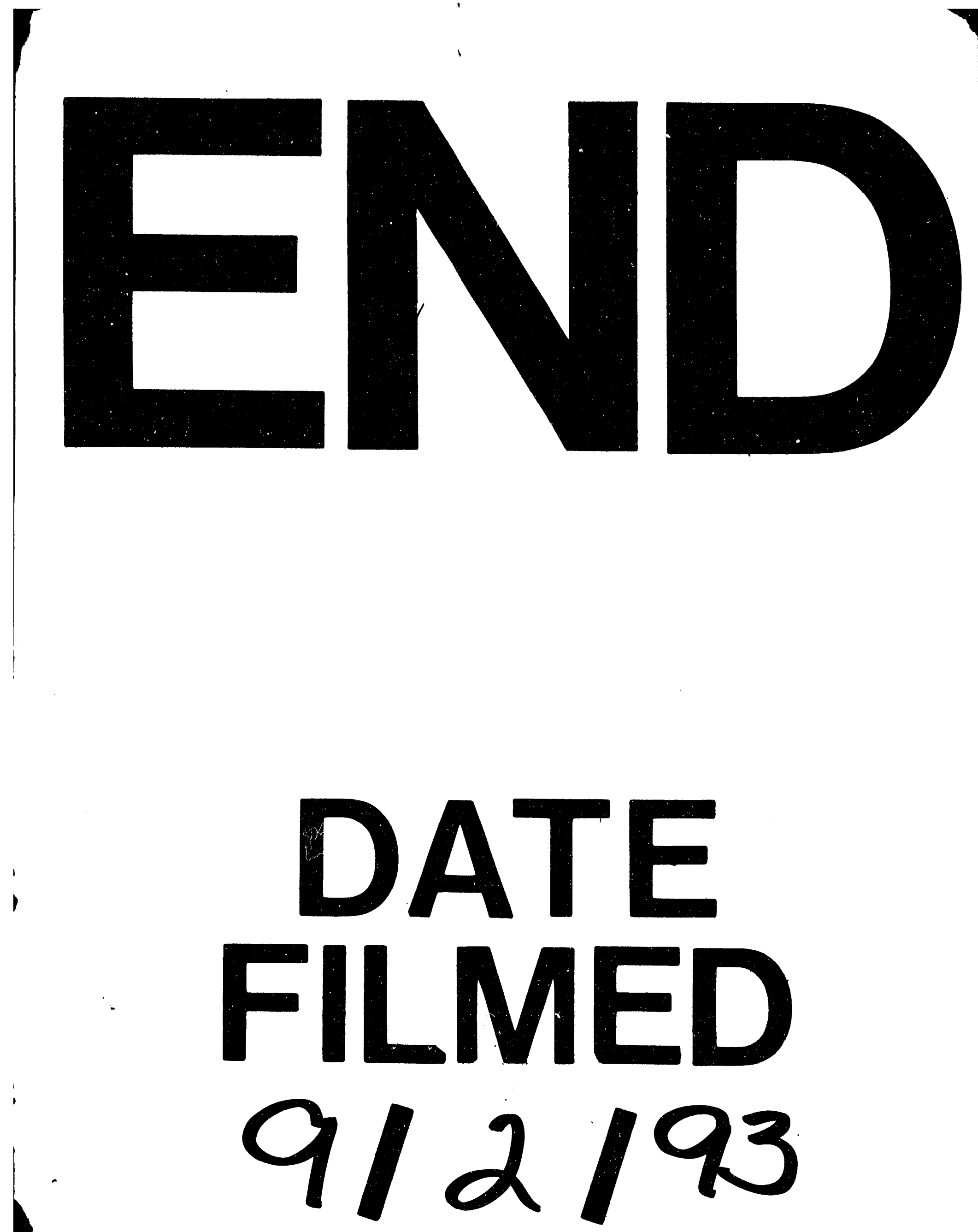